\title{
Dietary guidance and ileal enteroendocrine cells in patients with irritable bowel syndrome
}

\author{
TAREK MAZZAWI ${ }^{1,3}$ and MAGDY EL-SALHY ${ }^{2,3}$ \\ ${ }^{1}$ Division of Gastroenterology, Department of Clinical Medicine, University of Bergen, 5021 Bergen; \\ ${ }^{2}$ Division of Gastroenterology, Department of Medicine, Stord Hospital, Helse-Fonna, 5416 Stord; \\ ${ }^{3}$ National Centre for Functional Gastrointestinal Disorders, Department of Medicine, \\ Haukeland University Hospital, Helse-Bergen, 5021 Bergen, Norway
}

Received December 12, 2015; Accepted March 10, 2016

DOI: $10.3892 /$ etm.2016.3491

\begin{abstract}
The enteroendocrine cells of the ileum are stimulated by the luminal contents to release specific hormones that regulate its functions. The density of ileal enteroendocrine cells is abnormal in patients with irritable bowel syndrome (IBS), and the majority of patients with IBS associate their symptoms to the consumption of certain foodstuffs. The present study investigated the effect of dietary guidance on the enteroendocrine cells of the ileum in 11 patients with IBS. A total of 10 control subjects were also included. Each patient received three sessions of dietary guidance. Colonoscopies were performed on both controls and patients with IBS (at baseline and 3-9 months after the patients had received dietary guidance). Biopsy samples from the ileum were immunostained for all enteroendocrine cells and quantified by computerized image analysis. The densities of serotonin-immunoreactive cells in controls and in patients with IBS prior to and following dietary guidance were $35.5 \pm 5.7,38.7 \pm 7.1$ and $22.3 \pm 2.6$ cells $/ \mathrm{mm}^{2}$, respectively (mean \pm standard error of the mean; $\mathrm{P}=0.046$ ); the corresponding values for PYY-immunoreactive cells were $16.7 \pm 2.8,20.2 \pm 5.1$ and $21.3 \pm 2.7$ cells $/ \mathrm{mm}^{2}(\mathrm{P}=0.86)$. These results suggest that changes in enteroendocrine cell densities in the ileum along with changes in enteroendocrine cells throughout the gastrointestinal tract may contribute to the improvement in IBS symptoms following dietary guidance.
\end{abstract}

\section{Introduction}

The pathogenesis of irritable bowel syndrome (IBS) is complex and is believed to be multifactorial, involving the diet, an altered neuroendocrine system, abnormal intestinal

Correspondence to: Dr Tarek Mazzawi, Division of Gastroenterology, Department of Clinical Medicine, University of Bergen, Jonas Lies vei 87, 5021 Bergen, Norway

E-mail: tarek.mazzawi@med.uib.no

Key words: diet, enteroendocrine cells, image analysis, immunohistochemistry, ileum, irritable bowel syndrome microbiota, genetics and low-grade inflammation (1). More than $60 \%$ of patients with IBS associate their symptom development to diet (2-4). The most important dietary triggers are insoluble fiber and the rapidly fermentable but poorly absorbed carbohydrates termed fermented oligosaccharides, disaccharides, monosaccharides, and polyols (FODMAPs) (5-9).

Enteroendocrine cells are scattered among the various types of epithelial cells lining the gastrointestinal (GI) lumen (10-13). Patients with IBS have abnormal densities of enteroendocrine cells in various segments of the GI tract (14-31). Following dietary guidance about a low-FODMAP diet and changing the proportions of fat, protein, and carbohydrates in their diet, patients with IBS reportedly experience improvements in their IBS symptoms and quality of life (32) along with normalization of the densities of several types of enteroendocrine cells in the stomach $(33,34)$ and the large intestine $(35,36)$. The density of the total enteroendocrine cells as detected by chromogranin $\mathrm{A}(\mathrm{Cg} \mathrm{A})$ in the ileum also changes following dietary guidance (37). However, the types of enteroendocrine cells that are affected in these interventions are not clear. The present study was therefore undertaken to determine the types of ileal enteroendocrine cells that are affected following dietary guidance in the same cohort of patients with IBS.

\section{Materials and methods}

Patients and controls. Male and female patients aged 18-70 years who were referred to the Division of Gastroenterology at the Stord Hospital (Stord, Norway) were included in the study. All of the patients fulfilled Rome-III criteria (38) for an IBS diagnosis. The exclusion criteria included pregnant or lactating women, and the presence of severe psychiatric or organic/systemic diseases, drug abuse and previous abdominal surgery (except for appendectomy, cesarean section and hysterectomy).

A group of 10 subjects ( 7 females and 3 males) with a mean age of 51 years (age range, 26-70 years) were included in the study as controls. Subjects in the control group did not present symptoms associated with IBS. These control subjects underwent colonoscopy due to health concerns not associated with IBM, including diagnosis of a family member with cancer of the GI tract $(n=6)$ or a history of GI bleeding $(n=4)$ where 
the source of bleeding was identified as hemorrhoids $(n=3)$ or angiodysplasia $(n=1)$.

The study was performed in accordance with the Declaration of Helsinki (39) and was approved by the local Committee for Medical Research Ethics in Western Norway (no. 2010/2650-2). All of the patients provided both oral and written consents to participate.

Study design. In total, 46 patients (35 females and 11 males) were initially included in the study. Their mean age was 35 years (age range, 18-69 years). All of the patients received physical examinations and blood tests to exclude inflammation, infection, and other organic diseases. The patients also received a total of three sessions of individualized dietary guidance given by a nurse experienced in diet and IBS. The sessions lasted for $45 \mathrm{~min}$ each and were provided at intervals of at least 2 weeks (Fig. 1). The patients were examined with colonoscopies prior to the first session and at 3-9 months (median, 4 months) following the last session of dietary guidance.

Individualized dietary guidance. Dietary guidance was delivered orally using charts, and in written illustrations. The main focus of the first session was to provide general information regarding IBS, and to emphasize the importance of a regular eating pattern and the foodstuffs that worsen IBS symptoms such as poorly absorbable FODMAPs and insoluble dietary fiber. The patients were allowed to consume lactose-free milk and other lactose-free dairy products during the study. For a period of 2 weeks, the patients were instructed to test alternating diets that were rich and then poor in protein, fat and carbohydrates, each for 3-4 days. During this period the patients had to register in a diary their daily consumption of food and fluids (times and types) in addition to any associated symptoms, including the frequency and degree of abdominal pain and abdominal distension along with the stool frequency and consistency. No food supplements containing probiotics, antibiotics or other medications were allowed during the study, with the exception of where specified otherwise.

During the second session, the information given during the first session was briefly repeated. The nurse focused on using the information from the diary of the patient to identify the foodstuffs that triggered the IBS symptoms. Based on this information the patients were instructed to alter the proportions of protein, fat, and carbohydrates, to avoid FODMAP-rich foodstuffs as well as insoluble fiber, and to consume vegetables and fruits containing lower amounts of FODMAPs and insoluble fiber.

In the third session, each patient gave feedback regarding the dietary guidance to the nurse. With the help of the nurse, a suitable diet was designed for the patient to follow until the end of the study.

Dietary assessment. The dietary intake was assessed using the Norwegian Mother and Child Study food frequency questionnaire (MoBa FFQ; www.fhi.no/dokumenter/011fbd699d. pdf) (40), which reports the frequency and the sizes of food meal portions and beverages consumed during a certain period of time. The nutrient content of the diet was calculated using FoodCalc (41). The MoBa FFQ inquires about the consumption of 225 foodstuffs and also identifies the dietary habits of the subject, including the consumption of any oral supplements, according to typical Norwegian meal patterns. The questionnaire was developed and validated by the Norwegian Institute of Public Health in Oslo, Norway $(42,43)$. The patients completed the MoBa FFQ form prior to the first session and again $\geq 3$ months following the third session of individualized dietary guidance. The forms were delivered on the same day on which a colonoscopy was scheduled (32).

Colonoscopy. Colonoscopy was performed on both the patients and controls following preparation of their bowels via consumption of sodium picosulfate (Picoprep ${ }^{\circledR}$; Ferring Pharmaceuticals, Saint-Prex, Switzerland) the day before the procedure. Four biopsies were taken from the ileum during the colonoscopy.

Histopathology and immunohistochemistry. The biopsy samples were fixed overnight in $4 \%$ buffered paraformaldehyde (cat. no. 329847; Den Norske Eterfabrikk, Oslo, Norway) and embedded in paraffin (Cellwax; GCA-0305-00A; Cellpath Ltd., Newtown, Powys, UK). The tissue samples were then sectioned at a thickness of $5 \mu \mathrm{m}$ using Leica SM2000 R Sliding microtome (Leica Biosystems Nussloch $\mathrm{GmbH}$, Heidelberger, Germany) and placed on the slides, with each slide containing two tissue samples sectioned at $50 \mu \mathrm{m}$ apart (distance in the paraffinated samples). The tissue sections were stained with hematoxylin (Cellpath Ltd.) and eosin (Merck KGaA, Darmstadt, Germany), and immunostained using the avidin-biotin complex (ABC) method with a Vectastain ABC kit (cat. no. PK-4000; Vector Laboratories, Inc., Burlingame, CA, USA) and the chromogen 3,3'-diaminobenzidine peroxidase substrate (DAB) kit (cat. no. SK-4105; Vector Laboratories, Inc.) as described previously (40). The tissue sections were hydrated and immersed in $0.01 \%$ hydrogen peroxide in phosphate-buffered saline (PBS; $\mathrm{pH}=7.4$ ) for $10 \mathrm{~min}$ in order to inhibit endogenous peroxidase activity. Following washing with PBS, the tissue sections were treated with $1 \%$ bovine serum albumin for 30 min to block non-specific binding sites, followed by incubation with the primary antibody at room temperature for $1 \mathrm{~h}$. The following primary antisera/antibodies were used: Monoclonal mouse anti-serotonin (cat. no. 5HT-209; Dako, Glostrup, Denmark), polyclonal anti-porcine peptide YY (PYY; cat. no. PYY 11A; Alpha-Diagnostic International, Inc., San Antonio, TX, USA), polyclonal rabbit anti-synthetic human pancreatic polypeptide (PP; cat. no. 114; Diagnostic Biosystems, Pleasanton, CA, USA), polyclonal rabbit anti-porcine glicentin/glucagon (also known as oxyntomodulin; cat. no. BP508; Acris Antibodies, Herford, Germany), and polyclonal rabbit anti-synthetic human somatostatin (cat. no. A566; Dako); these antibodies were each diluted to $1: 1,500,1: 1,000,1: 800,1: 400$ and 1:200, respectively.

The sections were then washed in PBS and incubated with biotinylated swine anti-mouse immunoglobulin G (Dako) diluted to 1:200 for $30 \mathrm{~min}$ at room temperature. Following washing in PBS buffer, the tissue sections were incubated for $30 \mathrm{~min}$ with avidin-biotin-peroxidase complex (Vector Laboratories) diluted to 1:100, and then submerged in DAB and counterstained with hematoxylin. 
Table I. Demographic characteristics of the study subjects.

\begin{tabular}{lccc}
\hline IBS subtype and controls & Number of patients & Age range and mean (years) & Females/males \\
\hline IBS-D & 5 & $31-45(37.0)$ & $2 / 3$ \\
IBS-C & 4 & $28-36(31.0)$ & $3 / 1$ \\
IBS-M & 2 & $24-30(27.0)$ & $2 / 0$ \\
Controls & 10 & $26-70(51)$ & $7 / 3$ \\
\hline
\end{tabular}

IBS-D, irritable bowel syndrome-diarrhea predominant; IBS-C, irritable bowel syndrome-constipation predominant; IBS-M, irritable bowel syndrome-mixed.

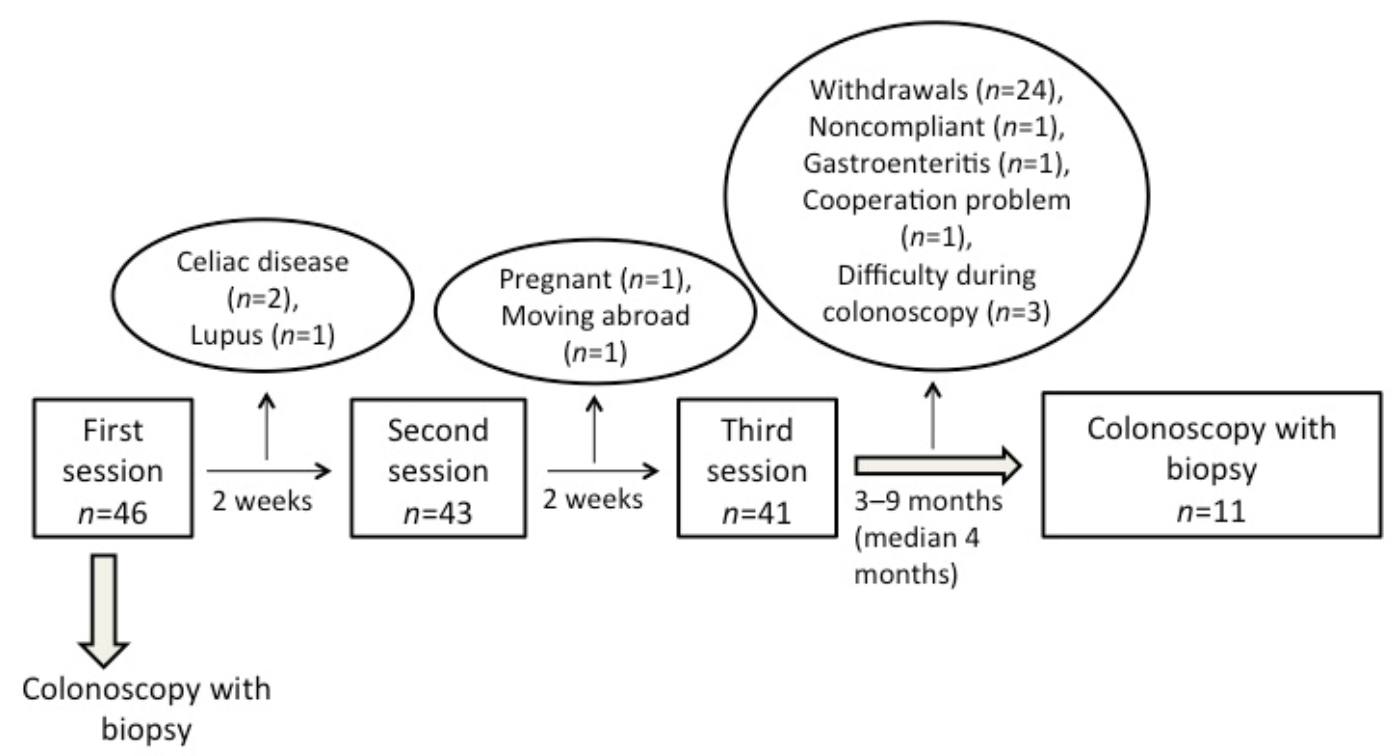

Figure 1. Study flow chart.

Computerized image analysis. The density of each type of enteroendocrine cell in the ileum of patients with IBS and the controls was measured using Olympus Cell D software (version 5.1; Olympus, Tokyo, Japan). The number of enteroendocrine cells and the area of epithelial cells were measured in 10 randomly selected fields per slide, using Olympus BX50 DIC light microscope (Olympus, Oslo, Norway) at a magnification of $x 40$. Each field represented a tissue area of $0.14 \mathrm{~mm}^{2}$. The density of the enteroendocrine cells was expressed as the number of cells $/ \mathrm{mm}^{2}$ of epithelium. The data from the fields were tabulated, computed, and automatically analyzed statistically. The quantification was conducted by the same scientist (Dr Tarek Mazzawi) while he was blinded to the identity of the tissue sections.

Statistical analysis. Statistical analysis was performed using GraphPad Prism version 6 (GraphPad Software Inc., La Jolla, CA, USA). The data are presented as mean \pm standard error of the mean values. Comparisons of the gender and age between the controls and the patients were conducted using Fisher's exact test and a Mann-Whitney test, respectively. Paired t-tests were used to compare the data from patients prior to and following dietary guidance. $\mathrm{P}<0.05$ was considered to indicate a statistically significant difference.

\section{Results}

Patients and controls. In total, 46 patients were included in the study and received individualized dietary guidance, of which 14 (9 females and 5 males) with a mean age of 33 years (age range, 21-44 years) completed the study (Fig. 1). In three of the original 46 patients ( 2 females and 1 male) it was technically difficult to intubate the ileocecal valve during colonoscopy, and so only 11 patients ( 7 females and 4 males) with a mean age of 33 years (age range, 24-44 years) were included in the final study analysis. The gender distribution did not differ significantly between the patients and controls $(\mathrm{P}=1)$, whereas the age distribution did $(\mathrm{P}=0.009)$. The demographic characteristics of the subjects are summarized in Table I.

Four of the 11 patients who completed the study used one or a combination of the following: Proton-pump inhibitors $(n=2)$, thyroxin-substitution tablets $(n=2)$, asthma inhalator $(n=1)$, angiotensin II receptor antagonist antihypertension tablets $(n=1)$, anti-allergy tablets $(n=3)$, contraceptive pills $(n=2)$, and antidepressant/anxiolytic tablets $(n=2)$. These patients were instructed not to take any kind of proton-pump inhibitors or antacids for 1 week prior to beginning the study or during the study. 


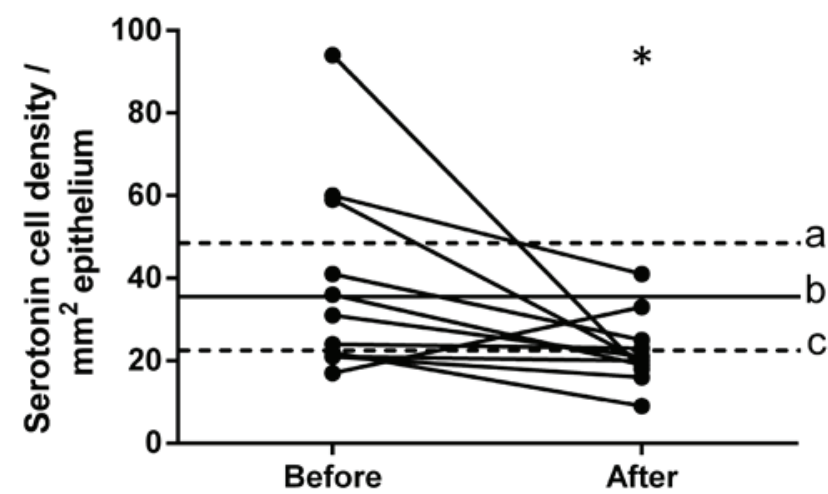

Figure 2. Densities of serotonin-immunoreactive cells in the ileum of patients with IBS prior to and following dietary guidance. The dashed lines labeled ' $a$ ' and 'c' indicate the upper and lower limits of the $95 \%$ confidence interval for the serotonin cell density in the control subjects, respectively, whereas line ' $b$ ' indicates the mean serotonin cell density. ${ }^{*} \mathrm{P}<0.05$, vs. the patients with IBS prior to dietary guidance. IBS, irritable bowel syndrome.

Dietary assessment. The dietary changes in the current study are described in detail elsewhere (32). Briefly, the total consumption of daily fruits and vegetables rich in FODMAPs decreased significantly from $16.2 \pm 5.3 \mathrm{~g}$ prior to receiving dietary guidance to $9.2 \pm 3.2 \mathrm{~g}$ following dietary guidance $(\mathrm{P}=0.02)$. However, no significant change was observed in the total daily consumption of fiber prior to $(27.4 \pm 2.5 \mathrm{~g})$ and following $(23.1 \pm 2.2 \mathrm{~g})$ dietary guidance $(\mathrm{P}=0.09)(32)$.

Colonoscopy, histopathology, and immunohistochemistry. The ileum was both macroscopically and microscopically normal in both the patients and controls. Serotonin-, PYY-, PP-, oxyntomodulin (enteroglucagon)-, and somatostatin-immunoreactive cells were found predominantly in the crypts of the ileum in all subjects (patients and controls). These cells were either basket-or flask-shaped. The numbers of PP-, oxyntomodulin (enteroglucagon)-, and somatostatin-immunoreactive cells were too low to be reliably quantified in the examined biopsy material.

\section{Computerized image analysis}

Serotonin. The density of serotonin-immunoreactive cells in the controls was $35.5 \pm 5.7$ cells $/ \mathrm{mm}^{2}$. The density of these cells in patients with IBS was $38.7 \pm 7.1$ cells $/ \mathrm{mm}^{2}$ prior to dietary guidance and $22.3 \pm 2.6$ cells $/ \mathrm{mm}^{2}$ following dietary guidance (Figs. 2 and 3). The densities of serotonin-immunoreactive cells in the patients with IBS moved closer to the mean values within the $95 \%$ confidence interval of the controls following dietary guidance. The paired $t$-test indicated a significant decrease in the density of serotonin-immunoreactive cells in IBS patients following dietary guidance $(\mathrm{P}=0.046)$.

$P Y Y$. The density of PYY-immunoreactive cells in the controls was $16.7 \pm 2.8$ cells $/ \mathrm{mm}^{2}$. The densities of these cells in patients with IBS prior to and following dietary guidance were $20.2 \pm 5.1$ and $21.3 \pm 2.7$ cells $/ \mathrm{mm}^{2}$, respectively (Figs. 4 and 5). The densities of PYY-immunoreactive cells in the patients with IBS were closer to the mean values within the $95 \%$ confidence interval of the controls following dietary guidance. The paired t-test showed no significant change in

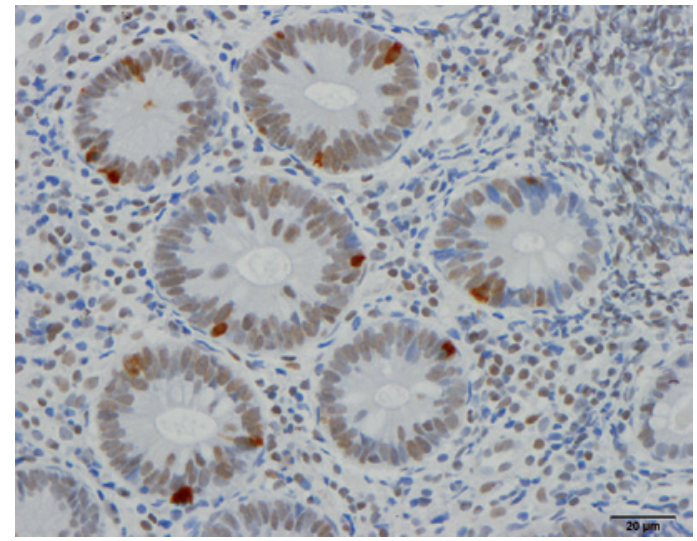

B

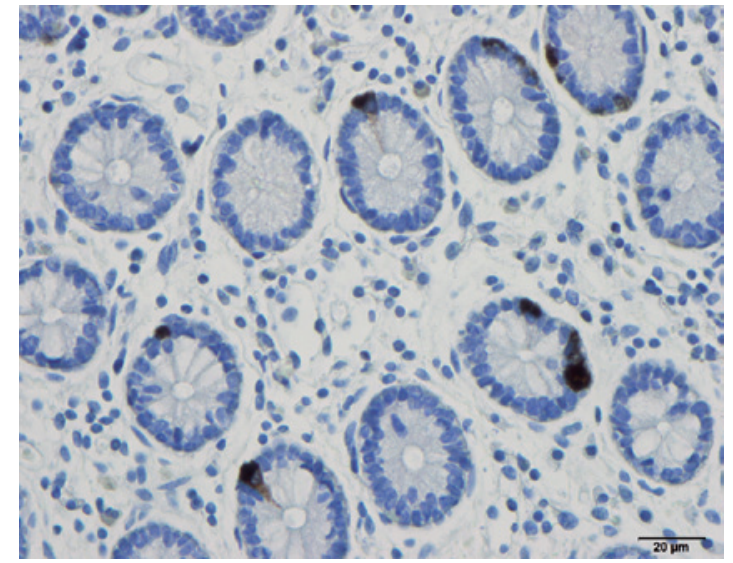

C

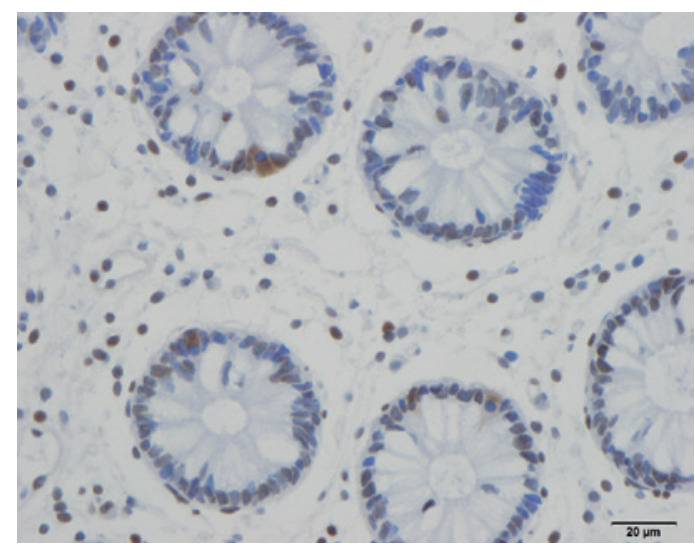

Figure 3. Serotonin-immunoreactive cells in the ileum of a (A) control subject, and of a patient with irritable bowel syndrome (B) prior to and (C) following dietary guidance using a light microscope at magnification of $\mathrm{x} 40$.

the density of PYY-immunoreactive cells in patients with IBS following dietary guidance $(\mathrm{P}=0.86)$.

\section{Discussion}

Dropout rates of $\leq 48 \%$ have been reported in previous clinical studies involving IBS $(6,45-48)$. The current study had an even higher dropout rate, which was likely due to the demanding study design that included undergoing two colonoscopies and having to follow a strict diet for a minimum of 3 months. The majority of the patients withdrew their consents when they experienced symptom improvement following dietary guidance, and due to their unwillingness to participate again in an invasive examination, namely a second colonoscopy. 


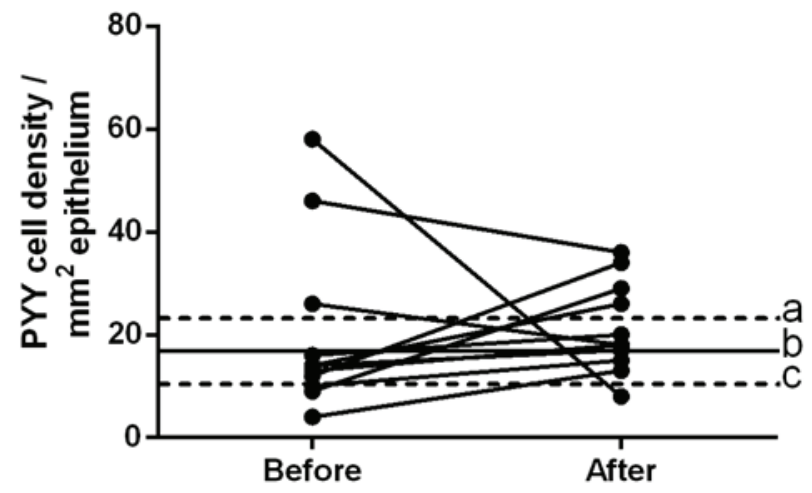

Figure 4. Densities of PYY-immunoreactive cells in the ileum of patients with IBS prior to and following dietary guidance. The dashed lines labeled 'a' and ' $c$ ' indicate the upper and lower limits of the $95 \%$ confidence interval for the PYY cell density in the control subjects, respectively, whereas line ' $b$ ' indicates the mean PYY cell density. IBS, irritable bowel syndrome. PYY, peptide YY.

A

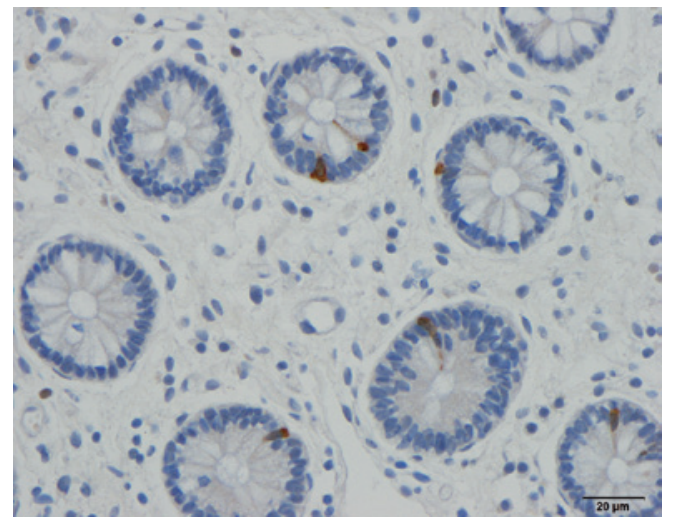

B

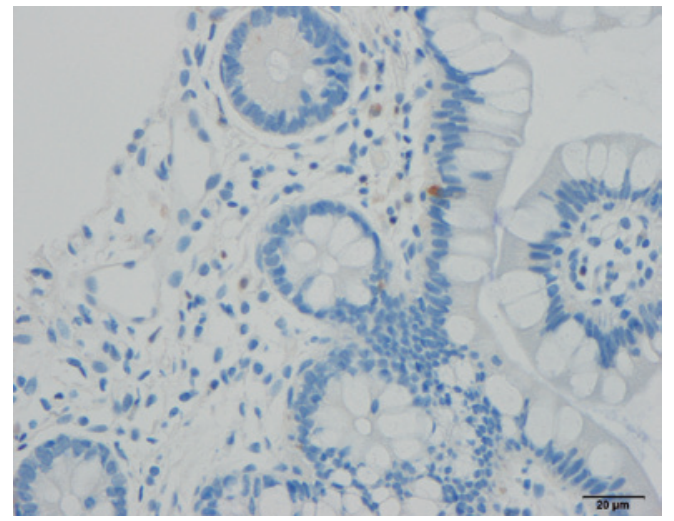

C

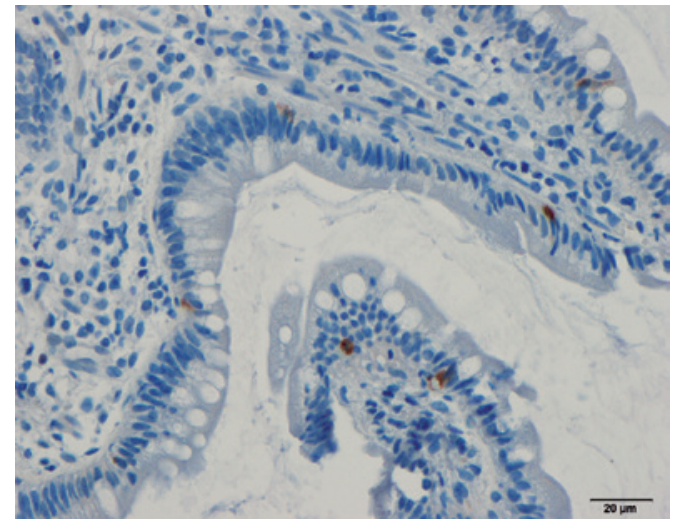

Figure 5. PYY-immunoreactive cells in the ileum of a (A) control subject, and of a patient with irritable bowel syndrome (B) prior to and (C) following dietary guidance using a light microscope at magnification of $\mathrm{x} 40$. PYY, peptide YY.
Additional factors further increased the dropout rate to $76 \%$, including the exclusion of some patients following diagnosis with organic diseases, pregnancy, moving abroad, and technically difficult colonoscopies. Nevertheless, although only a small number of patients completed this study, the changes in diet among these patients affected the enteroendocrine cells of the ileum in the same way as the dietary changes affected other investigated segments of the GI tract in previous studies (33-37). It is worth noting that neither age nor gender affects the densities of the intestinal enteroendocrine cells $(11,35,49)$.

The enteroendocrine cells project specific microvilli that interact with the GI luminal contents (particularly with nutrients) and respond by releasing specific hormones that regulate various functions of the GI tract $(12,50-58)$. Serotonin stimulates the intestinal motility, accelerates intestinal transit (59-67), and activates the submucosal sensory branch (termed the Meissner's plexus) of the enteric nervous system that carries sensation from the GI tract to the central nervous system and modulates the visceral sensitivity of the GI tract (17,59,63-65). PYY is a major regulator of the 'ileal brake' and stimulates the absorption of water and electrolytes $(17,68)$.

A previous study involving the same cohort of patients with IBS investigated in the present study (37) demonstrated that the total enteroendocrine cells of the ileum, as detected by $\mathrm{CgA}$, changed significantly following dietary guidance. These changes may be attributed to changes in the densities of serotonin- and PYY-immunoreactive cells. The densities of these cells became similar to those of the control subjects after the patients received dietary guidance. There is a dynamic interaction between foodstuffs and enteroendocrine cells (69). These cells have a rapid turnover rate from stem cells of $\sim 2-6$ days $(70,71)$. It can be speculated that a change of diet following dietary guidance may alter the differentiation of enteroendocrine cells and explain the observed changes in the densities of enteroendocrine cells in the ileum as well as the other parts of the GI tract in patients with IBS.

In conclusion, the cumulative changes in the enteroendocrine cells throughout the GI tract, namely in the stomach $(33,34)$, the small intestine (37), and the large intestine $(35,36)$, in patients with IBS following dietary guidance may have contributed to the improvements in the symptoms and quality of life of the patients with IBS that were observed during the present study, results which were concordant with those of a previous report (32). The findings of the present study highlight the role of the enteroendocrine cells in the pathophysiology of IBS and the usage of dietary guidance and diet manipulation as a first line step in the management of IBS symptoms.

\section{Acknowledgements}

The present study was supported by a grant from Helse-Fonna (grant no. 40415).

\section{References}

1. El-Salhy M, Gundersen D, Hatlebakk JG and Hausken T: Irritable bowel syndrome. Nova Science Publisher, New York, 2012. 
2. Simrén M, Månsson A, Langkilde AM, Svedlund J, Abrahamsson H, Bengtsson U and Björnsson ES: Food-related gastrointestinal symptoms in the irritable bowel syndrome. Digestion 63: 108-115, 2001.

3. Monsbakken KW, Vandvik PO and Farup PG: Perceived food intolerance in subjects with irritable bowel syndrome-etiology, prevalence and consequences. Eur J Clin Nutr 60: 667-672, 2006

4. Williams EA, Nai X and Corfe BM: Dietary intakes in people with irritable bowel syndrome. BMC Gastroenterol 11: 9, 2011.

5. El-Salhy M, Ostgaard H, Gundersen D, Hatlebakk JG and Hausken T: The role of diet in the pathogenesis and management of irritable bowel syndrome (Review). Int J Mol Med 29: 723-731, 2012.

6. Ostgaard H, Hausken T, Gundersen D and El-Salhy M: Diet and effects of diet management on quality of life and symptoms in patients with irritable bowel syndrome. Mol Med Rep 5: 1382-1390, 2012.

7. Biesiekierski JR, Rosella O, Rose R, Liels K, Barrett JS, Shepherd SJ, Gibson PR and Muir JG: Quantification of fructans, galacto-oligosacharides and other short-chain carbohydrates in processed grains and cereals. J Hum Nutr Diet 24: 154-176, 2011.

8. Muir JG, Rose R, Rosella O, Liels K, Barrett JS, Shepherd SJ and Gibson PR: Measurement of short-chain carbohydrates in common Australian vegetables and fruits by high-performance liquid chromatography (HPLC). J Agric Food Chem 57: 554-565, 2009.

9. Muir JG, Shepherd SJ, Rosella O, Rose R, Barrett JS and Gibson PR: Fructan and free fructose content of common Australian vegetables and fruit. J Agric Food Chem 55: 6619-6627, 2007

10. El-Salhy M: Ghrelin in gastrointestinal diseases and disorders: A possible role in the pathophysiology and clinical implications (review). Int J Mol Med 24: 727-732, 2009.

11. Sandström O and El-Salhy M: Ageing and endocrine cells of human duodenum. Mech Ageing Dev 108: 39-48, 1999.

12. Sternini C, Anselmi L and Rozengurt E: Enteroendocrine cells: A site of 'taste' in gastrointestinal chemosensing. Curr Opin Endocrinol Diabetes Obes 15: 73-78, 2008.

13. Moran GW, Leslie FC, Levison SE, Worthington J and McLaughlin JT: Enteroendocrine cells: Neglected players in gastrointestinal disorders? Therap Adv Gastroenterol 1: 51-60, 2008

14. Coates MD, Mahoney CR, Linden DR, Sampson JE, Chen J, Blaszyk H, Crowell MD, Sharkey KA, Gershon MD, Mawe GM and Moses PL: Molecular defects in mucosal serotonin content and decreased serotonin reuptake transporter in ulcerative colitis and irritable bowel syndrome. Gastroenterology 126: 1657-1664, 2004.

15. Dizdar V, Spiller R, Singh G, Hanevik K, Gilja OH, El-Salhy M and Hausken T: Relative importance of abnormalities of CCK and 5-HT (serotonin) in Giardia-induced post-infectious irritable bowel syndrome and functional dyspepsia. Aliment Pharmaco Ther 31: 883-891, 2010.

16. El-Salhy M, Gilja OH, Gundersen D, Hatlebakk JG and Hausken T: Duodenal chromogranin a cell density as a biomarker for the diagnosis of irritable bowel syndrome. Gastroenterol Res Pract 2014: 462856, 2014

17. El-Salhy M, Gilja OH, Gundersen D, Hatlebakk JG and Hausken T: Endocrine cells in the ileum of patients with irritable bowel syndrome. World J Gastroenterol 20: 2383-2391, 2014

18. El-Salhy M, Gilja OH, Gundersen D and Hausken T: Endocrine cells in the oxyntic mucosa of the stomach in patients with irritable bowel syndrome. World J Gastrointest Endosc 6 : 176-185, 2014

19. El-Salhy M, Gilja OH and Hausken T: Chromogranin A cells in the stomachs of patients with sporadic irritable bowel syndrome. Mol Med Rep 10: 1753-1757, 2014

20. El-Salhy M, Gundersen D, Hatlebakk JG, Gilja OH and Hausken T: Abnormal rectal endocrine cells in patients with irritable bowel syndrome. Regul Pept 188: 60-65, 2014

21. El-Salhy M, Gundersen D, Ostgaard H, Lomholt-Beck B, Hatlebakk JG and Hausken T: Low densities of serotonin and peptide YY cells in the colon of patients with irritable bowel syndrome. Dig Dis Sci 57: 873-878, 2012.

22. El-Salhy M, Lillebø E, Reinemo A and Salmelid L: Ghrelin in patients with irritable bowel syndrome. Int J Mol Med 23: 703-707, 2009.

23. El-Salhy M, Lomholt-Beck B and Hausken T: Chromogranin A as a possible tool in the diagnosis of irritable bowel syndrome. Scand J Gastroenterol 45: 1435-1439, 2010
24. El-Salhy M, Mazzawi T, Gundersen D and Hausken T: Chromogranin A cell density in the rectum of patients with irritable bowel syndrome. Mol Med Rep 6: 1223-1225, 2012.

25. El-Salhy M, Vaali K, Dizdar V and Hausken T: Abnormal small-intestinal endocrine cells in patients with irritable bowel syndrome. Dig Dis Sci 55: 3508-3513, 2010.

26. El-Salhy M, Wendelbo IH and Gundersen D: Reduced chromogranin A cell density in the ileum of patients with irritable bowel syndrome. Mol Med Rep 7: 1241-1244, 2013.

27. Kim HS, Lim JH, Park H and Lee SI: Increased immunoendocrine cells in intestinal mucosa of postinfectious irritable bowel syndrome patients 3 years after acute Shigella infection-an observation in a small case control study. Yonsei Med J 51: 45-51, 2010.

28. Park JH, Rhee PL, Kim G, Lee JH, Kim YH, Kim JJ, Rhee JC and Song SY: Enteroendocrine cell counts correlate with visceral hypersensitivity in patients with diarrhoea-predominant irritable bowel syndrome. Neurogastroenterol Motil 18: 539-546, 2006.

29. Wang SH, Dong L, Luo JY, Gong J, Li L, Lu XL and Han SP Decreased expression of serotonin in the jejunum and increased numbers of mast cells in the terminal ileum in patients with irritable bowel syndrome. World J Gastroenterol 13: 6041-6047, 2007.

30. Spiller RC, Jenkins D, Thornley JP, Hebden JM, Wright T, Skinner M and Neal KR: Increased rectal mucosal enteroendocrine cells, T lymphocytes, and increased gut permeability following acute Campylobacter enteritis and in post-dysenteric irritable bowel syndrome. Gut 47: 804-811, 2000.

31. Lee KJ, Kim YB, Kim JH, Kwon HC, Kim DK and Cho SW: The alteration of enterochromaffin cell, mast cell, and lamina propria $\mathrm{T}$ lymphocyte numbers in irritable bowel syndrome and its relationship with psychological factors. J Gastroenterol Hepatol 23: 1689-1694, 2008

32. Mazzawi T, Hausken T, Gundersen D and El-Salhy M: Effects of dietary guidance on the symptoms, quality of life and habitual dietary intake of patients with irritable bowel syndrome. Mol Med Rep 8: 845-852, 2013.

33. Mazzawi T, Gundersen D, Hausken T and El-Salhy M: Increased gastric chromogranin A cell density following changes to diets of patients with irritable bowel syndrome. Mol Med Rep 10: 2322-2326, 2014

34. Mazzawi T, Hausken T, Gundersen D and El-Salhy M: Effect of dietary management on the gastric endocrine cells in patients with irritable bowel syndrome. Eur J Clin Nutr 69: 519-524, 2015.

35. Mazzawi T, Gundersen D, Hausken T and El-Salhy M: Increased chromogranin a cell density in the large intestine of patients with irritable bowel syndrome after receiving dietary guidance. Gastroenterol Res Pract 2015: 823897, 2015.

36. Mazzawi T, Hausken T, Gundersen D and El-Salhy M: Dietary guidance normalizes large intestinal endocrine cells densities in patients with irritable bowel syndrome. Eur J Clin Nutr 70: 175-181, 2016.

37. Mazzawi T and El-Salhy M: Changes in small intestinal chromogranin-A immunoreactive cells after patients with irritable bowel syndrome receive dietary guidance Submitted, 2015.

38. Longstreth GF, Thompson WG, Chey WD, Houghton LA, Mearin F and Spiller RC. Functional bowel disorders. Gastroenterology 130: 1480-1491, 2006.

39. World Medical Association: Declaration of Helsinki. Ethical Principles for Medical Research Involving Human Subjects. Jahrbuch für Wissenschaft Und Ethik 14: 233-238, 2009.

40. Meltzer HM, Brantsaeter AL, Ydersbond TA, Alexander J and Haugen M: Methodological challenges when monitoring the diet of pregnant women in a large study: experiences from the Norwegian Mother and Child Cohort Study (MoBa). Matern Child Nutr 4: 14-27, 2008.

41. Rimestad AH, Borgejordet Å, Vesterhus KN, Sygnestveit K, Løken EB and Trygg K: Den Store Matvaretabellen [The Norwegian Food Composition Table]. Norwegian Food Safety Authority, Oslo, 2001 (In Norwegian).

42. Masson LF, McNeill G, Tomany JO, Simpson JA, Peace HS, Wei L, Grubb DA and Bolton-Smith C: Statistical approaches for assessing the relative validity of a food-frequency questionnaire: Use of correlation coefficients and the kappa statistic. Public Health Nutr 6: 313-321, 2003.

43. Brantsaeter AL, Haugen M, Alexander J and Meltzer HM: Validity of a new food frequency questionnaire for pregnant women in the Norwegian Mother and Child Cohort Study (MoBa). Matern Child Nutr 4: 28-43, 2008. 
44. El-Salhy M, Stenling R and Grimelius L: Peptidergic innervation and endocrine cells in the human liver. Scand J Gastroenterol 28: 809-815, 1993.

45. Enck P, Klosterhalfen S and Kruis W: Determination of placebo effect in irritable bowel syndrome. Dtsch Med Wochenschr 130 1934-1937, 2005 (In German).

46. Abdul-Baki H, El Hajj II, Elzahabi L, Azar C, Aoun E, Skoury A, Chaar $\mathrm{H}$ and Sharara AI: A randomized controlled trial of imipramine in patients with irritable bowel syndrome. World $\mathbf{J}$ Gastroenterol 15: 3636-3642, 2009.

47. Zernicke KA, Campbell TS, Blustein PK, Fung TS, Johnson JA, Bacon SL and Carlson LE: Mindfulness-based stress reduction for the treatment of irritable bowel syndrome symptoms: A randomized wait-list controlled trial. Int J Behav Med 20: 385-396, 2013

48. Halmos EP, Power VA, Shepherd SJ, Gibson PR and Muir JG: A diet low in FODMAPs reduces symptoms of irritable bowe syndrome. Gastroenterology 146: 67-75.e5, 2014.

49. Sandström O and el-Salhy M: Human rectal endocrine cells and aging. Mech Ageing Dev 108: 219-226, 1999.

50. Lee J, Cummings BP, Martin E, Sharp JW, Graham JL, Stanhope KL, Havel PJ and Raybould HE: Glucose sensing by gut endocrine cells and activation of the vagal afferent pathway is impaired in a rodent model of type 2 diabetes mellitus Am J Physiol Regul Integr Comp Physiol 302: R657-R666, 2012.

51. Parker HE, Reimann F and Gribble FM: Molecular mechanisms underlying nutrient-stimulated incretin secretion. Expert Rev Mol Med 12: e1, 2010.

52. Raybould HE: Nutrient sensing in the gastrointestinal tract: Possible role for nutrient transporters. J Physiol Biochem 64 349-356, 2008.

53. San Gabriel A, Nakamura E, Uneyama H and Torii K: Taste, visceral information and exocrine reflexes with glutamate through umami receptors. J Med Invest 56 (Suppl): S209-S217, 2009.

54. Rudholm T, Wallin B, Theodorsson E, Näslund E and Hellström PM: Release of regulatory gut peptides somatostatin, neurotensin and vasoactive intestinal peptide by acid and hyperosmolal solutions in the intestine in conscious rats. Regul Pept 152: 8-122, 2009.

55. Sternini C: Taste receptors in the gastrointestinal tract. IV Functional implications of bitter taste receptors in gastrointestinal chemosensing. Am J Physiol Gastrointest Liver Physiol 292: G457-G461, 2007.

56. Buchan AM: Nutrient tasting and signaling mechanisms in the Gut III. Endocrine cell recognition of luminal nutrients. Am J Physiol 277: G1103-G1107, 1999.
57. Montero-Hadjadje M, Elias S, Chevalier L, Benard M, Tanguy Y, Turquier V, Galas L, Yon L, Malagon MM, Driouich A, et al: Chromogranin A promotes peptide hormone sorting to mobile granules in constitutively and regulated secreting cells: Role of conserved N-and C-terminal peptides. J Biol Chem 284: 12420-12431, 2009.

58. Shooshtarizadeh P, Zhang D, Chich JF, Gasnier C, Schneider F, Haïkel Y, Aunis D and Metz-Boutigue MH: The antimicrobial peptides derived from chromogranin/secretogranin family, new actors of innate immunity. Regul Pept 165: 102-110, 2010.

59. Gershon MD and Tack J: The serotonin signaling system: From basic understanding to drug development for functional GI disorders. Gastroenterology 132: 397-414, 2007.

60. Tack JF, Janssens J, Vantrappen G and Wood JD: Actions of 5-hydroxytryptamine on myenteric neurons in guinea pig gastric antrum. Am J Physiol 263: G838-G846, 1992.

61. Michel K, Sann H, Schaaf C and Schemann M: Subpopulations of gastric myenteric neurons are differentially activated via distinct serotonin receptors: Projection, neurochemical coding, and functional implications. J Neurosci 17: 8009-8017, 1997.

62. Tack J, Coulie B, Wilmer A, Andrioli A and Janssens J: Influence of sumatriptan on gastric fundus tone and on the perception of gastric distension in man. Gut 46: 468-473, 2000.

63. Gershon MD: Plasticity in serotonin control mechanisms in the gut. Curr Opin Pharmacol 3: 600-607, 2003.

64. Gershon MD: 5-Hydroxytryptamine (serotonin) in the gastrointestinal tract. Curr Opin Endocrinol Diabetes Obes 20: 14-21 2013.

65. Gershon MD: Serotonin is a sword and a shield of the bowel: Serotonin plays offense and defense. Trans Am Clin Climatol Assoc 123: 268-280; discussion 280, 2012.

66. Gershon MD: Review article: Roles played by 5-hydroxytryptamine in the physiology of the bowel. Aliment Pharmacol Ther 13 (Suppl 2): S15-S30, 1999

67. Gershon MD, Wade PR, Kirchgessner AL and Tamir H: 5-HT receptor subtypes outside the central nervous system. Roles in the physiology of the gut. Neuropsychopharmacology 3: 385-395, 1990.

68. El-Salhy M, Mazzawi T, Gundersen D, Hatlebakk JG and Hausken T: The role of peptide YY in gastrointestinal diseases and disorders (review). Int J Mol Med 31: 275-282, 2013.

69. El-Salhy M, Gilja OH, Gundersen D, Hatlebakk JG and Hausken T: Interaction between ingested nutrients and gut endocrine cells in patients with irritable bowel syndrome (review). Int J Mol Med 34: 363-371, 2014

70. Höcker M and Wiedenmann B: Molecular mechanisms of enteroendocrine differentiation. Ann N Y Acad Sci 859: 160-174, 1998.

71. Inokuchi H, Fujimoto $S$ and Kawai K: Cellular kinetics of gastrointestinal mucosa, with special reference to gut endocrine cells. Arch Histol Jpn 46: 137-157, 1983 